
87-97.

\title{
PENGARUH MODEL PEMBELAJARAN KOOPERATIF TIPE TSTS TERINTEGRASI NILAI TRI HITA KARANA TERHADAP HASIL BELAJAR IPS
}

\author{
${ }^{1} \mathrm{Ni}$ Kadek Ratna, ${ }^{2}$ Gusti Ngurah Japa, ${ }^{3} \mathrm{Ni}$ Wayan Arini \\ 1,2,3 Jurusan Pendidikan Dasar Universitas Pendidikan Ganesha \\ e-mail: ni.kadek.ratna@undiksha.ac.id, igustingurah.japa@undiksha.ac.id, \\ niwayan.arini@undiksha.ac..id
}

\begin{abstract}
ABSTRAK
Permasalahan dalam penelitian ini adalah hasil belajar IImu Pengetahuan Sosial siswa yang masih rendah. Penelitian ini bertujuan untuk mengetahui apakah terdapat perbedaan yang signifikan hasil belajar IImu Pengetahuan Sosial tema cita-citaku antara siswa yang dibelajarkan dengan model pembelajaran kooperatif tipe Two Stay Two Stray terintegrasi Nilai Tri Hita Karana dan siswa yang tidak dibelajarkan dengan model pembelajaran kooperatif tipe Two Stay Two Stray terintegrasi Nilai Tri Hita Karana pada siswa kelas IV SD di Gugus IV Kecamatan Sukasada tahun pelajaran 2018/2019. Jenis penelitian ini adalah penelitian eksperimen semu. Populasi penelitian ini berjumlah 165 siswa. Sampel penelitian ditentukan dengan menggunakan teknik culster random sampling. Data hasil belajar Ilmu Pengetahuan Sosial dikumpulkan menggunakan tes objektif kemudian dianalisis menggunakan teknik analisis statistik deskriptif dan statistik inferensial (uji-t). Berdasarkan hasil analisis data, diperoleh $t_{\text {hitung }}=9,69$ dan $t_{\text {tabel }}$ (taraf signifikansi $\left.5 \%\right)=2,021$. Hal ini berarti $t_{\text {hitung }}>t_{\text {tabel }}$ sehingga dapat disimpulkan bahwa terdapat perbedaan yang signifikan hasil belajar IImu Pengetahuan Sosial tema cita-citaku antara siswa yang dibelajarkan dengan model pembelajaran kooperatif tipe Two Stay Two Stray terintegrasi Nilai Tri Hita Karana dan siswa yang tidak dibelajarkan dengan model pembelajaran kooperatif tipe Two Stay Two Stray terintegrasi Nilai Tri Hita Karana pada siswa kelas IV SD di Gugus IV Kecamatan Sukasada Tahun Pelajaran 2018/2019.
\end{abstract}

Kata kunci: hasil belajar IPS, THK, TSTS

\section{ABSTRACT}

The problem in this study is the student's Social Sciences learning outcomes are still low. This study aims to determine whether there are significant differences in the Social Sciences learning outcomes of my ideals between students who are taught by the Two Stay Two Stray type cooperative learning model integrated Tri Hita Karana Value and students who are not taught by the Two Stay Two cooperative learning model Stray integrated the Tri Hita Karana Value for 4th grade elementary school students in Cluster IV Sukasada District 2018/2019 academic year. This type of research is quasi-experimental research. The population of this study amounted to 165 students. The study sample was determined using the culster random sampling technique. Social Sciences learning outcomes data were collected using objective tests and then analyzed using descriptive statistical analysis techniques and inferential statistics (t-test). Based on the results of data analysis, obtained tcount $=9.69$ and t table (significance level of $5 \%$ ) $=2.021$. This means that tcount> ttable so that it can be concluded that there are significant differences in Social Sciences learning outcomes my ideals between students who are taught by the Two Stay Two Stray type cooperative learning model integrated Tri Hita Karana Value and students who are not taught by cooperative learning models type Two Stay Two Stray integrated Tri Hita Karana Value in fourth grade elementary school students in Cluster IV Sukasada District in 2018/2019 Academic Year.

Key words : Social Learning Outcomes, THK, TSTS 
Ni Kadek Ratna, I Gusti Ngurah Japa, Ni Wayan Arini . (2019). Jurnal Pendidikan Multikultural Indonesia. Vol. 2 (2) pp. 87-97.

\section{PENDAHULUAN}

Kurikulum merupakan suatu rencana yang disusun untuk melancarkan proses pembelajaran dibawah bimbingan dan tanggung jawab pihak sekolah. Tanpa adanya kurikulum proses pembelajaran tidak akan berjalan. Kurikulum tidak hanya kegiatan yang direncanakan saja, melainkan peristiwa-peristiwa yang terjadi dalam sekolah di bawah pengawasan sekolah. Indonesia terus berupaya menyempurnakan kurikulum untuk meningkatkan mutu pendidikan. Saat ini pendidikan dasar dan menengah mengalami pergantian kurikulum. Kurikulum yang digunakan saat ini yaitu kurikulum 2013, yang mana kurikulum ini menggunakan pendekatan saintifik dalam pembelajarannya. Pada Lampiran Permendikbud Nomor 103 Tahun 2014, tercantum bahwa pendekatan saintifik memiliki lima pengalaman belajar yang harus dilakukan oleh siswa dalam proses pembelajaran yaitu: (1) Mengamati; (2) Menanya; (3) Mengumpulkan informasi/mencoba; (4) Menalar; (5) Mengomunikasikan.

Keberhasilan dalam pembelajaran Kurikulum 2013 diukur dari tiga aspek. Menurut Pebruanti (2015:368) "aspek penilaian pembelajaran pada kurikulum 2013, yaitu: aspek sikap, aspek pengetahuan, dan aspek psikomotor". Aspek sikap dapat diperoleh dari aktivitas menjalankan, menghargai, menghayati dalam proses pembelajaran. Aspek kognitif dapat diperoleh dari memahami, mengingat, menganalisis, mengevaluasi. Kemudian aspek psikomotor dapat diperoleh dari aktivitas mencoba, menanya, menalar, menyaji, mencipta.

Pada kurikulum 2013 diharapkan mampu membekali siswa baik secara intelektual, emosional, dan spritual. Menurut Prastowo (2013:217) dalam kurikulum 2013 "kegiatan pembelajaran di sekolah dasar dilaksanakan berdasarkan pada standar kompetensi lulusan, kompetensi inti, dan kompetensi dasar". Standar kompetensi lulusan digunakan untuk merumuskan kompetensi dasar. Untuk mempermudah oprasionalnya maka kompetensi lulusan pada ranah sikap dibagi menjadi dua. Pertama, sikap spiritual yang berkaitan dengan iman dan takwa. Kedua, sikap sosial yang berkaitan dengan akhlak mulia, mandiri, demokratis, dan bertanggung jawab (Prastowo, 2013). Kompetensi inti merupakan pengikat berbagai kompetensi dasar yang harus dihasilkan dengan mempelajari tiap mata pelajaran. Menurut Prastowo (2013:219) "rumusan kompetensi inti adalah $\mathrm{KI}-1$ untuk kompetensi inti sikap spiritual, KI-2 untuk kompetensi inti sikap sosial, KI-3 untuk kempetensi inti pengetahuan, dan $\mathrm{KI}-4$ untuk kompetensi inti keterampilan".

Selain menggunakan pendekatan saintifik didalam pembelajarannya, kurikulum 2013 juga menggunakan pendekatan pembelajaran tematik integratif. Pendekatan pembelajaran tematik integratif merupakan pendekatan yang menggabungkan berbagai kompetensi dasar dari berbagai muatan pelajaran. IImu Pengetahuan Sosial (IPS) merupakan salah satu muatan pelajaran yang digabungkan dalam satu tema pada kurikulum 2013. Susanto (2013:137) berpendapat bahwa "IPS adalah ilmu pengetahuan yang mengkaji berbagai disiplin ilmu sosial humaniora serta kegiatan dasar manusia yang dikemas secara ilmiah dalam rangka memberi wawasan dan pemahaman yang mendalam kepada peserta didik, khususnya tingkat dasar dan menengah". Sedangkan menurut Murda dan Yudiana (2016:25) menyatakan bahwa "IPS adalah ilmu pengetahuan yang memadukan sejumlah konsep pilihan dari cabang-cabang ilmu sosial dan ilmu lainnya serta kemudian diolah berdasarkan prinsip pendidikan dan didaktik untuk dijadikan program pengajaran pada tingkat persekolahan".

Suatu pembelajaran memiliki sebuah tujuan, begitu pula dengan pembelajaran IPS yang memiliki tujuan. Tujuan pembelajaran IPS adalah mengembangkan siswa untuk memiliki mental yang positif, sadar dan peduli akan lingkungannya, mampu beradaptasi dengan baik di keluarga, sekolah, maupun masyarakat. Susanto (2013:145) berpendapat bahwa, tujuan utama pembelajaran IPS ialah untuk mengembangkan potensi peserta didik agar peka terhadap masalah sosial yang terjadi di masyarakat, memiliki sikap mental positif terhadap perbaikan segala ketimpangan yang terjadi, dan terampil mengatasi setiap masalah yang terjadi sehari-hari baik yang menimpa dirinya sendiri maupun yang menimpa masyarakat.

Pembelajaran IPS diharapkan mampu membentuk siswa menjadi orang yang berkarakter, cakap, cerdas, dan mampu memenuhi Kriteria Ketuntasan Minimal (KKM). Namun harapan tersebut berbanding terbalik pada kenyataan dilapangan. Berdasarkan hasil wawancara yang dilakukan dengan wali kelas IV SD di gugus IV Kecamatan Sukasada, diperoleh informasi bahwa hasil belajar IPS masih rendah, yang disebabkan oleh beberapa faktor diantaranya: 1) Kurangnya

Pengaruh Model Pembelajaran Kooperatif Tipe Tsts Terintegrasi Nilai Tri Hita Karana Terhadap Hasil Belajar IPS 

87-97.

minat siswa untuk belajar; 2) Siswa tidak berkonsetrasi saat proses pembelajaran; 3) Siswa kurang aktif dalam proses pembelajaran.

Selain melakukan wawancara, juga dilakukan observasi kegiatan pembelajaran di kelas. Dari observasi yang dilakukan di Gugus IV Kecamatan Sukasada, ditemukan beberapa masalah yang menyebabkan rendahnya hasil belajar siswa yaitu sebagai berikut: 1) Siswa tidak bersemangat dalam mengikuti pembelajaran hal ini terlihat saat guru mengajukan pertanyaan kepada siswa namun, tidak ada siswa yang menjawab pertanyaan guru; 2) Guru tidak menggunakan model pembelajaran yang bervariasi, sehingga siswa bosan selama proses pembelajaran; 3) Kurangnya perhatian siswa terhadap pemaparan materi yang disampaikan oleh guru. Berdasarkan hasil pencatatan dokumen yang telah dilakukan pada tanggal 7-8 Januari 2019, maka diperoleh data hasil UAS pelajaran IPS kelas IV SD di Gugus IV Kecamatan Sukasada yang masih rendah, dapat dilihat pada tabel di bawah ini.

Tabel 1

Nilai Rata-rata UAS Muatan Pelajaran IPS kelas IV SD di Gugus IV Kecamatan Sukasada Tahun Pelajaran 2018/2019

\begin{tabular}{|c|c|c|c|c|c|c|}
\hline No & Nama Sekolah & $\begin{array}{c}\text { Jumlah } \\
\text { siswa }\end{array}$ & $\begin{array}{c}\text { Rata-rata } \\
\text { Nilai } \\
\text { Siswa }\end{array}$ & KKM & $\begin{array}{c}\text { Siswa yang } \\
\text { telah } \\
\text { mencapai } \\
\text { KKM }\end{array}$ & $\begin{array}{c}\text { Siswa yang } \\
\text { belum } \\
\text { mencapai } \\
\text { KKM }\end{array}$ \\
\hline
\end{tabular}

\begin{tabular}{lllllll}
\hline 1 & SD Negeri 1 Sukasada & 23 & 60,35 & 65 & 7 & 16 \\
2 & SD Negeri 2 Sukasada & 19 & 58,5 & 67 & 3 & 16 \\
3 & SD Negeri 3 Sukasada & 36 & 54,3 & 68 & 3 & 33 \\
4 & SD Negeri 4 Sukasada & 12 & 59,1 & 75 & 2 & 10 \\
5 & SD Negeri 5 Sukasada & 13 & 58,4 & 65 & 5 & 8 \\
6 & SD Negeri 1 Ambengan & 14 & 57,3 & 65 & 4 & 10 \\
7 & SD Negeri 2 Ambengan & 23 & 49,0 & 64 & 4 & 19 \\
8 & SD Negeri 3 Ambengan & 25 & 56,0 & 63 & 4 & 21 \\
& Jumlah & 165 & - & - & 32 & 133 \\
\hline
\end{tabular}

Berdasarkan tabel di atas, dapat dilihat dari jumlah 165 siswa masih terdapat 133 siswa atau sama dengan $80,60 \%$ belum mencapai KKM. Tingginya jumlah siswa yang tidak mencapai KKM menunjukkan bahwa masih rendahnya hasil belajar siswa pada muatan pelajaran IPS di Gugus IV Kecamatan Sukasada. Untuk meningkatkan hasil belajar siswa yang rendah, perlu adanya proses pembelajaran IPS yang lebih menarik, hal ini dapat dilakukan dengan guru mengemas pembelajaran yang menarik dengan menggunakan model pembelajaran yang bervariasi. Salah satu model pembelajaran yang dapat diterapkan pada muatan pelajaran IPS yaitu model pembelajaran kooperatif tipe Two Stay Two Stray. Model pembelajaran kooperatif tipe Two Stay Two Stray merupakan model pembelajaran dengan menggunakan teknik dua tinggal dua bertamu (Shoimin 2014). Model pembelajaran ini dapat menciptakan suasana belajar yang aktif dengan adanya pola interaksi antar siswa melalui berdiskusi bersama dalam satu kelompok, kemudian menginformasikan hasil diskusinya kepada dua tamunya. Sedangkan Huda (2014:207) berpendapat bahwa "metode TS-TS merupakan sistem pembelajaran kelompok dengan tujuan agar siswa dapat saling bekerjasama, bertanggung jawab, saling membantu memecahkan masalah, dan saling mendorong satu sama lain untuk berprestasi. Motode ini juga melatih siswa

Pengaruh Model Pembelajaran Kooperatif Tipe Tsts Terintegrasi Nilai Tri Hita Karana Terhadap Hasil Belajar IPS 

87-97.

untuk bersosialisasi dengan baik". Setiap model pembelajaran memiliki langkah-langkah pembelajaran yang berbeda, begitupula dengan model pembelajaran Two Stay Two Stray. Shoimin (2014:223) berpendapat bahwa langkah-langkah model pembelajran Two Stay Two Stray sebagai berikut. (a) siswa bekerja sama dalam kelompok berempat seperti biasa. (b) setelah selesai, dua siswa dari masing-masing kelompok akan meninggalkan kelompoknya dan masingmasing bertamu ke kelompok yang lain. (c) dua siswa yang tinggal dalam kelompok bertugas membagikan hasil kerja dan informasi mereka ke tamu mereka. (d) tamu mohon diri dan kembali ke kelompok mereka sendiri dan melaporkan temuan mereka dari kelompok lain. (e) kelompok mencocokkan dan membahas hasil-hasil kerja mereka.

Adanya langkah-langkah pembelajaran yang jelas akan membuat proses pembelajaran berjalan dengan lancar dan menyenangkan. Kegiatan pembelajaran seperti ini tentunya dapat memberikan dampak positif bagi hasil belajar siswa. Selain itu kegiatan pembelajaran seperti ini dapat meningkatkan hubungan atau sikap sosial antar siswa, yang mana dalam Tri Hita Karana disebut dengan pawongan. Pawongan merupakan salah satu bagian dari Tri Hita Karana. Tiga penyebab kebahagiaan dalam ajaran agama Hindu disebut dengan Tri Hita Karana. Bagian-bagian dari Tri Hita Karana yaitu parahyangan, pawongan, dan palemahan. Dari ketiga penyebab kebahagiaan tersebut terdapat salah satu hubungan yang membahas mengenai hubungan manusia dengan manusia yang disebut pawongan. Manusia sangat bergantung dengan manusia yang lainnya dan sering dikatakan manusia merupakan makhluk sosial.

Model pembelajaran kooperatif tipe Two Stay Two Stary terintegrasi nilai Tri Hita Karana ini merupakan penggabungan antara model pembelajaran yang memberikan kesempatan kepada siswa untuk berdiskusi bersama, memecahkan suatu masalah dan saling berinteraksi dengan anggota yang lain untuk mendapatkan informasi lebih banyak lagi dan dengan menerapkan pengamalan nilai-nilai Tri Hita Karana. Guru menyelipkan mengenai nilai-nilai Tri Hita Karana pada saat pembelajaran, yang mana dalam Tri Hita Karana terdiri dari tiga bagian yaitu parahyangan, pawongan, dan palemahan. Parahyangan merupakan hubungan manusia dengan Tuhan, pawongan adalah hubungan manusia dengan manusia, dan palemahan adalah hubungan manusia dengan lingkungan. Penerapan nilai-nilai Tri Hita Karana dapat membentuk sikap siswa menjadi lebih baik. Berdasarkan uraian di atas, penerapan model pembelajaran kooperatif tipe Two Stay Two Stray terintegrasi nilai Tri Hita Karana diharapkan dapat meningkatkan hasil belajar IPS siswa kelas IV SD. Untuk itu perlu dilaksanakan penelitian dengan judul "Pengaruh Model Pembelajaran Kooperatif Tipe Two Stay Two Stray Terintegrasi Nilai Tri Hita Karana Terhadap Hasil Belajar IImu Pengetahuan Sosial Tema Cita-citaku Pada Siswa Kelas IV SD Di Gugus IV Kecamatan Sukasada Tahun Pelajaran 2018/2019". Tujuan dari pelaksanaan penelitian ini adalah untuk mengetahui apakah terdapat perbedaan yang signifikan hasil belajar Ilmu Pengetahuan Sosial tema cita-citaku antara siswa yang dibelajarkan dengan model pembelajaran kooperatif tipe Two Stay Two Stray terintegrasi Nilai Tri Hita Karana dan siswa yang tidak dibelajarkan dengan model pembelajaran kooperatif tipe Two Stay Two Stray.

\section{METODE}

Penelitaian ini merupakan penelitian kelas eksperimen dan kelas kontrol yang dilakukan pada siswa kelas IV SD Gugus IV Kecamatan Sukasada semester II tahun pelajaran 2018/2019. Penelitian kelas eksperimen dilakukan di SDN 3 Ambengan dan penelitian pada kelas kontrol dilakukan di SDN 1 Sukasada. Penelitian ini dilaksanakan pada bulan April sampai dengan bulan Mei 2019. Jenis penelitian yang dilakukan adalah kuasi eksperimen atau eksperimen semu. Tempat pelaksaan penelitian ini adalah di SD Negeri 3 Ambengan dan SD Negeri 1 Sukasada Kecamatan Sukasada. Populasi penelitian ini adalah semua siswa kelas IV Sekolah Dasar di Gugus IV Kecamatan Sukasada yang terdiri dari 8 Sekolah Dasar yaitu SD Negeri 1 Sukasada, SD Negeri 2 Sukasada, SD Negeri 3 Sukasada, SD Negeri 4 Sukasada, SD Negeri 5 Sukasada, SD Negeri 1 Ambengan, SD Negeri 2 Ambengan dan SD Negeri 3 Ambengan.

Penelitian ini menggunakan analisis ANAVA satu jalur untuk mengetahui kesetaraan kemampuan siswa di masing-masing SD. Berdasarkan hasil analisis diperoleh bahwa signifikansi nilai UAS IPS populasi tersebut adalah 0,36 dengan $F$ tabel 2,05. Perbandingan $F$ hitung dengan $F$ tabel ini menunjukkan bahwa $F$ hitung lebih kecil daripada $F$ tabel $(0,36<2,05)$. Hal ini menunjukkan bahwa nilai UAS IPS kedelapan sekolah tersebut adalah setara (sama). Sampel

Pengaruh Model Pembelajaran Kooperatif Tipe Tsts Terintegrasi Nilai Tri Hita Karana Terhadap Hasil Belajar IPS 

87-97.

penelitian ditentukan dengan menggunakan teknik cluster random sampling. Dantes (2012:43) berpendapat bahwa "kluster sampling (cluster sampling) adalah penarikan sampel yang didasarkan pada kelompok-kelompk sebagai anggota populasi”. Cara yang digunakan dalam melakukan teknik cluster random sampling yaitu dengan cara random. Cluster random sampling adalah cara pengambilan sampel berupa kelompok dengan randomisasi kelompok. Asumsi yang dianut pada teknik ini, bahwa masing-masing kelompok adalah relatif homogen, dan random dilakukan pada kelompok (Dantes, 2012:44). Setelah dilakukan uji kesetaraan populasi dan teknik cluster random sampling untuk menentukan sampel penelitian, maka sampel yang digunakan pada penelitian ini yaitu SDN 1 Sukasada sebagai kelas kontrol dan SDN 3 Ambengan sebagai kelas eksperimen. Penelitian ini menggunakan rancangan post-test only control group design yang secara prosedural mengikuti pola seperti ditunjukkan pada tabel 2 di bawah ini.

Tabel 2

Post-test Only Control Group Design

Kelas Treatment Post-test

Eksperimen $\mathrm{X}$ $\mathrm{X}$

$\mathrm{O}_{2}$

Metode yang digunakan untuk mengumpulkan data dalam penelitian ini adalah dengan menggunakan tes objektif (pilihan ganda) sebanyak 30 butir. Tes diberikan di akhir pembelajaran. Tes-tes yang telah disusun kemudian diujicobakan dengan menggunakan validitas isi, validitas butir, reliabilitas tes, tingkat kesukaran dan daya beda tes. Hasil uji coba instrumen dianalisis menggunakan Microsoft Office Excel 2007.

Analisis data yang digunakan dalam penelitian ini yaitu analisis statistik deskriptif dan uji prasyarat analisis. Analisis deskriptif yang digunakan untuk mencari skor modus, median,mean dan standar deviasi atau SD. Sedangkan analisis inferensial yang digunakan adalah uji-t. Dalam penelitian ini data disajikan dalam bentuk grafik polygon. Tujuan penyajian data ini adalah untuk menafsirkan sebaran data hasil belajar IPS siswa pada kelas eksperimen dan kontrol. Hubungan antara modus (Mo), median (Md), dan mean (M) dapat digunakan untuk menentukan kemiringan kurva polygon distribusi frekuensi. Pada uji prasyarat analisis dilakukan uji normalitas sebaran data, uji homogenitas varians, dan uji hipotesis. Uji normalitas sebaran data digunakan untuk meyakinkan bahwa sampel benar-benar berasal dari populasi yang berdistribusi normal, sehingga uji hipotesis dapat dilakukan. Untuk menghitung normalitas data rumus yang digunakan yaitu rumus Chi-Square. Uji homogenitas varians dilakukan untuk mencari tingkat kehomogenan secara dua pihak yang diambil dari kelas kontrol dan kelas eksperimen. Sedangkan teknik yang digunakan untuk menganalisis data guna menguji hipotesis penelitian adalah uji-t dengan rumus sebagai berikut.

$$
t=\frac{\bar{X}_{1}-\bar{X}_{2}}{\sqrt{\frac{\left(n_{1}-1\right) s_{1}{ }^{2}+\left(n_{2}-1\right) s_{2}{ }^{2}}{n_{1}+n_{2}-2}\left(\frac{1}{n_{1}}+\frac{1}{n_{2}}\right)}} \rightarrow \text { rumus (polled varians) }
$$

\section{HASIL DAN PEMBAHASAN}

(Koyan, 2012: 38)

Pembelajaran pada kelas eksperimen dilaksanakan pada tanggal 26 April sampai dengan tanggal 13 Mei dengan menggunakan RPP eksperimen yang telah disusun sebelum melakukan penelitian. Setelah pelaksanaan pembelajaran selesai, dilaksanakanlah pemberian post-test Pengaruh Model Pembelajaran Kooperatif Tipe Tsts Terintegrasi Nilai Tri Hita Karana Terhadap Hasil Belajar IPS 

87-97.

menggunakan instrumen yang telah diujicobakan dan dianalisis sebelumnya. Data hasil belajar kelas eksperimen diperoleh melalui memberikan post-test kepada 25 orang siswa. Sedangkan pembelajaran pada kelas kontrol dilaksanakan pada tanggal 18 April sampai dengan tanggal 13 Mei dengan menggunakan RPP kelas kontrol yang telah disusun oleh guru. Setelah pelaksanaan pembelajaran selesai, dilaksanakanlah pemberian post-test menggunakan instrument yang telah diujicobakan dan dianalisis sebelumnya. Data hasil belajar kelas kontrol diperoleh melalui memberikan post-test kepada 23 orang siswa. Berdasarkan hasil post-test tersebut diperoleh skor tertinggi yaitu 20 dan skor terendah yaitu 11 dari jumlah soal sebanyak 30 butir soal. Data yang terkumpul dalam penelitian ini berupa nilai tentang hasil belajar IPS siswa yang dibelajarkan dengan menggunakan model pembelajaran kooperatif tipe two stay two stray terintegrasi nilai tri hita karana dan siswa yang tidak dibelajarkan dengan menggunakan model pembelajaran kooperatif tipe two stay two stray terintegrasi nilai tri hita karana. Adapun hasil analisis data statistik deskriptif disajikan pada tabel 3 di bawah ini.

Tabel 3.

Rekapitulasi Hasil Perhitungan Analisis Data dengan Statistik Deskriptif

\begin{tabular}{ccc}
\hline Statistik & Kelas Eksperimen & Kelas Kontrol \\
\hline Mean & 24,44 & 16,2 \\
Median & 24,75 & 16 \\
Modus & 27,7 & 13,9 \\
Standar Deviasi & 3,3 & 2,49 \\
Varians & 10,89 & 6,18 \\
\hline
\end{tabular}

Berdasarkan tabel 3, dapat dideskripsikan pada kelas eksperimen menunjukkan bahwa mean $(M)=24,44$, median $(M d)=24,75$, dan modus $(M o)=27,7$. Sedangkan kelas kontrol menunjukkan bahwa mean $(M)=16,2$ median $(M d)=16$, dan modus $(M o)=13,9$. Secara deskriptif dapat disampaikan bahwa siswa yang dibelajarkan dengan model kooperatif tipe Two Stay Two Stray terintegrasi Nilai Tri Hita Karana lebih unggul dibandingkan dengan siswa yang tidak dibelajarkan dengan model kooperatif tipe Two Stay Two Stray terintegrasi Nilai Tri Hita Karana. Berdasarkan hasil analisis deskriptif data hasil belajar IPS kelas eksperimen, kemudian disajikan ke dalam kurva polygon. Tujuan penyajian data ini adalah untuk menafsirkan sebaran data hasil belajar kelas eksperimen. Hubungan antara mean, median, dan modus digunakan untuk menentukan kemiringan kurva polygon distribusi frekuensi. Kurva polygon data skor kelas eksperimen dapat dilihat pada gambar 1 . 
Ni Kadek Ratna, I Gusti Ngurah Japa, Ni Wayan Arini . (2019). Jurnal Pendidikan Multikultural Indonesia. Vol. 2 (2) pp. 87-97.

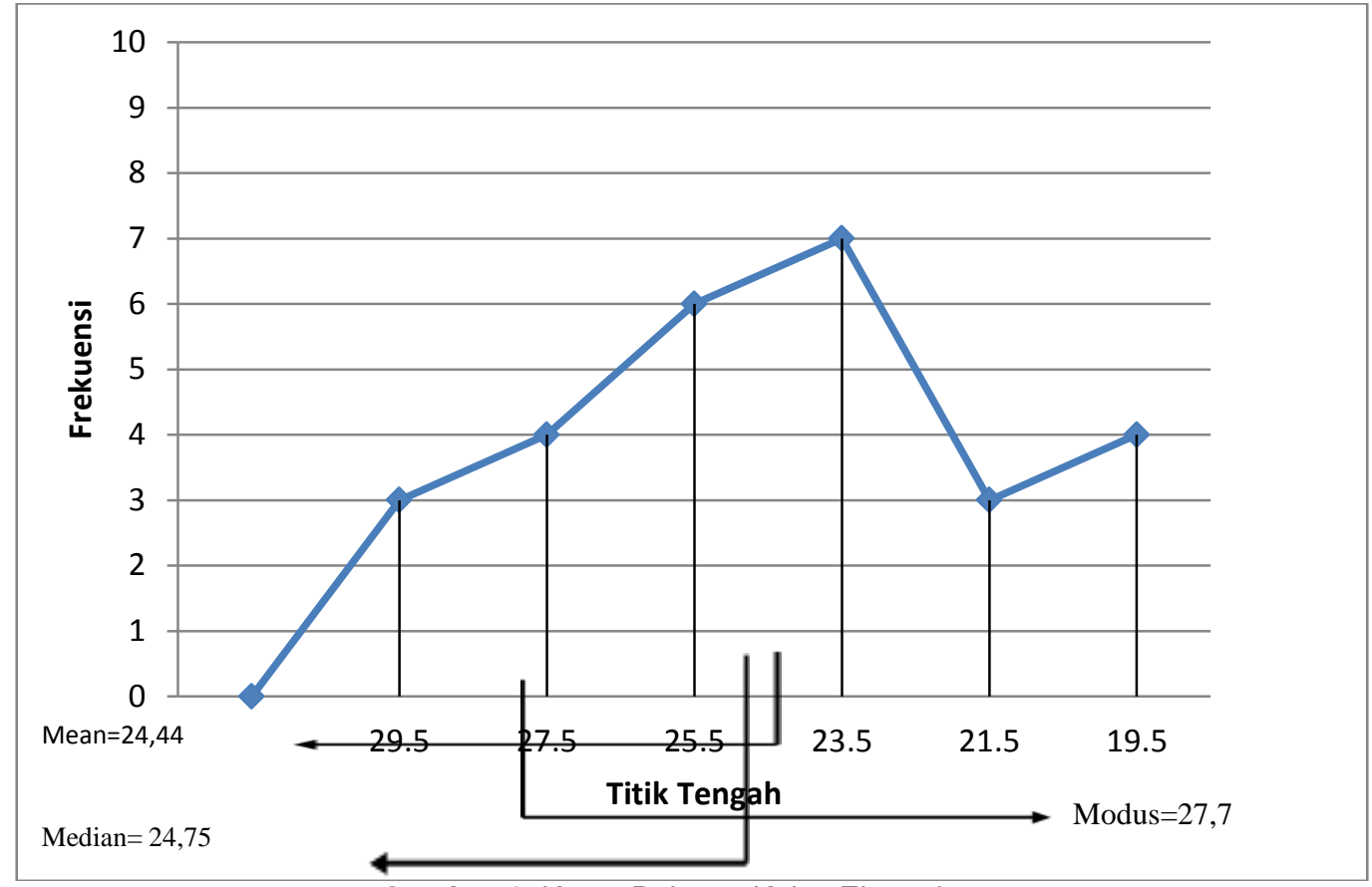

Gambar 1. Kurva Polygon Kelas Eksperimen

Berdasarkan kurva polygon di atas, tampak bahwa sebaran data pada siswa yang dibelajarkan dengan menggunakan model pembelajaran Two Stay Two Stray terintegrasi Nilai Tri Hita Karana merupakan juling negatif, karena modus lebih besar dari median dan median lebih besar dari mean (Mo>Me>M). Hal ini menunjukkan bahwa sebagian besar skor hasil belajar siswa kelas eksperimen cenderung tinggi. Berdasarkan hasil analisis data yang menunjukkan bahwa mean hasil belajar IPS siswa kelas eksperimen dengan menggunakan model pembelajaran kooperatif tipe Two Stay Two Stray terintegrasi Nilai Tri Hita Karana adalah 24,44. Jika dikonversikan ke dalam skala lima, nilai tersebut tergolong kriteria sangat tinggi.

Kemudian data hasil belajar IPS kelas kontrol, disajikan ke dalam kurva polygon. Tujuan penyajian data ini adalah untuk menafsirkan sebaran data hasil belajar kelas kontrol. Hubungan antara mean, median, dan modus digunakan untuk menentukan kemiringan kurva polygon distribusi frekuensi. Kurva polygon data skor kelas kontrol dapat dilihat pada gambar 2 . 
Ni Kadek Ratna, I Gusti Ngurah Japa, Ni Wayan Arini . (2019). Jurnal Pendidikan Multikultural Indonesia. Vol. 2 (2) pp. 87-97.

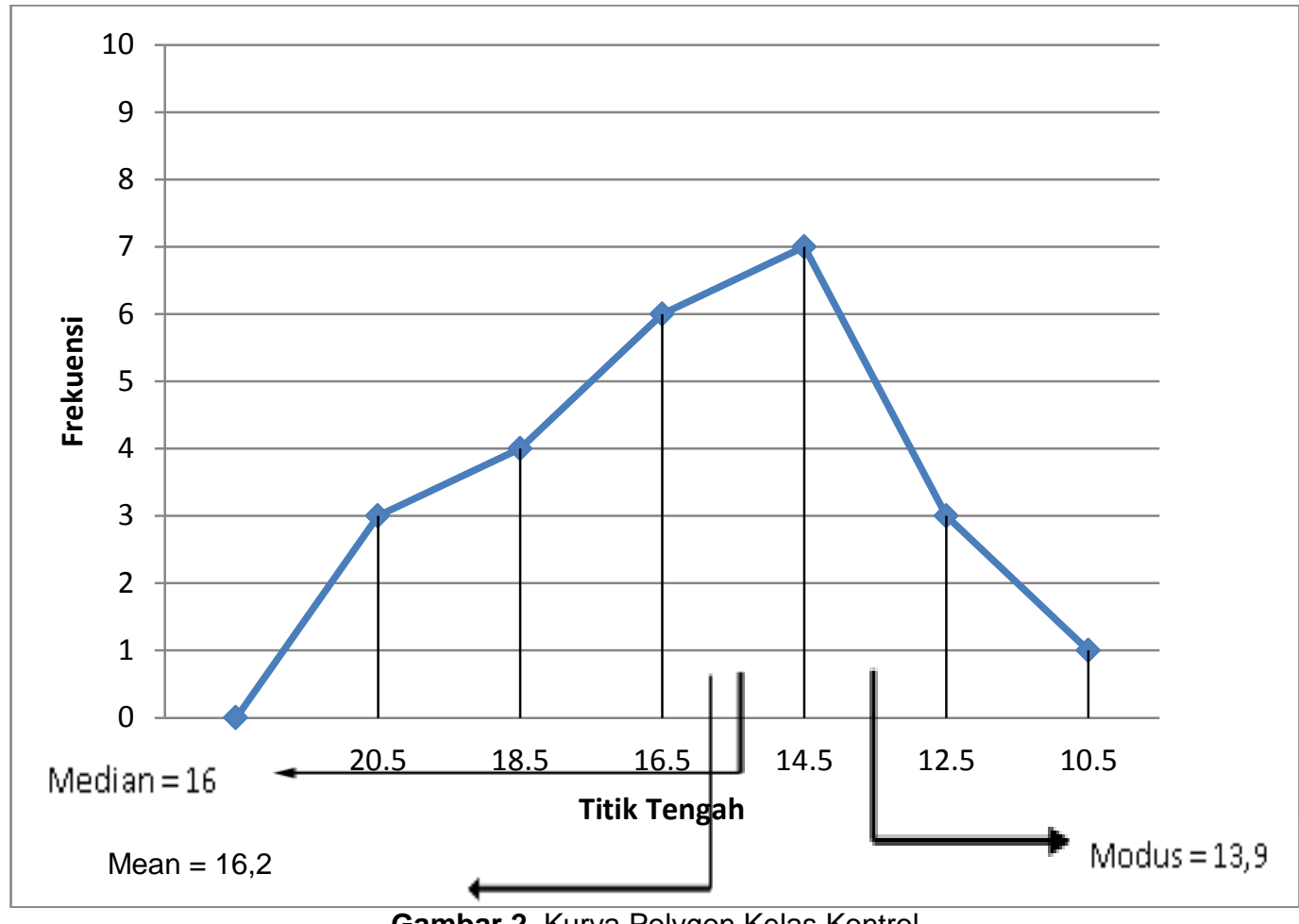

Gambar 2. Kurva Polygon Kelas Kontrol

Berdasarkan kurva polygon di atas, tampak bahwa sebaran data pada siswa yang tidak dibelajarkan dengan menggunakan model pembelajaran Two Stay Two Stray terintegrasi Nilai Tri Hita Karana merupakan juling positif, karena modus lebih kecil dari median dan median lebih kecil dari mean $(\mathrm{Mo}<\mathrm{Me}<\mathrm{M})$. Hal ini menunjukkan bahwa sebagian besar skor hasil belajar siswa kelas kontrol cenderung rendah. Untuk menentukan tinggi rendahnya hasil belajar IPS, skor rata-rata hasil belajar IPS siswa dikonversikan dengan menggunakan kriteria rata-rata ideal (Mi) dan standar deviasi ideal $\left(S D_{i}\right)$. Mean hasil belajar IPS siswa kelas kontrol adalah 16,2, jika dikonversikan ke dalam skala lima nilai tersebut tergolong kriteria sedang.

Sebelum dilakukan pengujian hipotesis dengan uji-t, terlebih dahulu dilakukan uji prasyarat terhadap sebaran data penelitian yaitu dengan melakukan uji normalitas dan uji homogenitas. Uji normalitas data dilakukan terhadap data hasil belajar IPS kelas eksperimen dan kelas kontrol. Berdasarkan analisis data yang telah dilakukan dengan menggunakan rumus Chi-Square, diperoleh data hasil belajar IPS kelas eksperimen dan kelas kontrol berdistribusi normal. Uji homogenitas varians menggunakan uji Fisher $(F)$, yang mana varians kedua kelompok tersebut berdistribusi homogen. Pengujian hipotesis dengan menggunakan rumus polled varians. Rekapitulasi hasil perhitungan uji-t antara kelas eksperimen dan kelas kontrol disajikan pada tabel 4.

Tabel 4.

Rekapitulasi hasil perhitungan $\mathrm{uji}-\mathrm{t}$

$\begin{array}{cccc}\text { Kelompok } & \mathbf{X} & \mathbf{t}_{\text {hitung }} & \begin{array}{c}\mathbf{t}_{\text {tabel }} \text { dengan taraf } \\ \text { signifikan } 5 \%\end{array}\end{array}$

\begin{tabular}{c|c|ccc}
\hline Eksperimen & 25 & 24,44 & 9,69 & 2,021 \\
\hline Kontrol & 23 & 16,2 & & \\
\hline
\end{tabular}

Keterangan : $\mathrm{N}=$ jumlah, $\bar{X}=$ rata-rata

Pengaruh Model Pembelajaran Kooperatif Tipe Tsts Terintegrasi Nilai Tri Hita Karana Terhadap Hasil 

87-97.

Berdasarkan hasil analisis uji-t hasil belajar IPS siswa diperoleh $t_{\text {hitung }}=9,69$ dan $t_{\text {tabel }}$ untuk dk $=46\left(\mathrm{dk}=\mathrm{n}_{1}+\mathrm{n}_{2}-2\right)$ dengan taraf signifikan $5 \%$ adalah 2,021. Dengan demikian $t_{\text {hitung }}>\mathrm{t}_{\text {tabel }}$ $(9,69>2,021)$, sehingga $\mathrm{H} 1$ diterima dan $\mathrm{H} 0$ ditolak. Hasil tersebut menunjukkan bahwa terdapat perbedaan yang signifikan hasil belajar IPS tema cita-citaku antara siswa yang dibelajarkan dengan model pembelajaran kooperatif tipe Two Stay Two Stray terintegrasi Nilai Tri Hita Karana dan siswa yang tidak dibelajarkan dengan model pembelajaran kooperatif tipe Two Stay Two Stray terintegrasi Nilai Tri Hita Karana pada siswa kelas IV SD di Gugus IV Kecamatan Sukasada Tahun Pelajaran 2018/2019.

Siswa kelas IV SD Negeri 3 Ambengan yang merupakan kelas eksperimen, diberikan perlakuan dengan menggunakan model pembelajaran kooperatif tipe Two Stay Two Stray terintegrasi Nilai Tri Hita Karana. Berdasarkan perlakuan yang diberikan, siswa kelas eksperimen mampu bekerjasama dalam kelompok, aktif, dan dapat berinteraksi dengan baik. Dalam kerjasama kelompok yang heterogen, siswa yang satu dengan yang lain saling bertukar pikiran, mengeluarkan pendapat dan ide mereka masing-masing melalui kegiatan tanya jawab, sehingga siswa yang berkemampuan rendah mendapatkan pengetahuan dari siswa yang berkemampuan tinggi. Adanya kegiatan tanya jawab antar siswa, dapat membuat siswa menjadi aktif dan kreatif. Siswa yang aktif dan kreatif dalam kerjasama kelompok akan menciptakan proses pembelajaran yang menyenangkan. Jika siswa merasa senang dalam belajar, maka materi yang dipelajari mudah dipahami dan berdampak pada hasil belajar siswa. Hal ini sejalan dengan pendapat Ridwanthi (2012:1) yang menyatakan bahwa "pembelajaran yang aktif, kreatif dan menyenangkan merupakan hal penting dalam proses pembelajaran, karena dengan pembelajaran yang aktif, kreatif dan menyenangkan dapat meningkatkan hasil belajar siswa".

Kegiatan diskusi dalam pembelajaran memberikan kesempatan kepada siswa untuk berkomunikasi antara siswa dan guru, siswa dan siswa lainnya, serta menyelesaikan tugas yang diberikan oleh guru. Tugas yang diberikan oleh guru tidak jauh dari ruang lingkup siswa, sehingga siswa mampu menyelesaikan tugasnya melalui kegiatan berdiskusi. Adanya kegiatan diskusi dapat meningkatkan minat siswa untuk mengikuti proses pembelajaran. Jika minat siswa telah tumbuh, maka siswa lebih termotivasi untuk belajar, sehingga hal tersebut berdampak pada hasil belajar siswa. Wardiana (2014) mengemukakan, minat belajar dapat mendorong dan memberikan motivasi kepada siswa untuk belajar lebih giat lagi.

Hal lain yang membuat pembelajaran yang dilakukan pada kelas eksperimen lebih berhasil yaitu adanya pembagian tugas yang jelas bagi seluruh siswa. Melalui pembagian tugas yang jelas, siswa belajar dengan sungguh-sungguh dan mampu mengurangi kegiatan siswa yang bersifat mengganggu pembelajaran. Pembagian tugas dalam pembelajaran kooperatif tipe Two Stay Two Stray terintegrasi Nilai Tri Hita Karana berupa pembagian tugas sebagai tamu dan penerima tamu. Dalam pembelajaran kooperatif tipe Two Stay Two Stray terintegrasi Nilai Tri Hita Karana siswa diberikan kesempatan untuk bertukar informasi ke kelompok lain melalui kegiatan bertamu. Saat bertamu siswa memberikan salam, bertutur kata yang sopan, dan menunjukkan perilaku yang baik. Hal ini sesuai dengan nilai Tri Hita Karana yaitu bidang pawongan. Dengan adanya bertamu, terbentuk interaksi dan komunikasi yang positif antar siswa. Kegiatan bertamu juga akan menjadikan siswa dalam masing-masing kelompok bertanggung jawab untuk menyelesaikan tugasnya. Selain saat bertamu, nilai Tri Hita Karana juga tampak pada awal kegiatan pembelajaran. Di awal pembelajaran siswa melakukan persembahyangan bersama, selain itu siswa juga membersihkan areal padmasana dan menghaturkan canang. Kegiatan ini sesuai dengan nilai Tri Hita Karana yaitu bidang parhyangan. Siswa juga melakukan pembersihan di lingkungan sekitar dan tempat duduk masing-masing. Hal ini dilakukan untuk menjaga lingkungan dan kelas agar tetap bersih dan nyaman. Kegiatan ini sesuai dengan nilai Tri Hita Karana yaitu bidang palemahan. Hal ini sejalan dengan pendapat Putra (2016:8) yang menyatakan bahwa "bagian Tri Hita Karana yang pertama Parhyangan, dengan penerapan bagian Tri Hita Karana ini siswa akan terbiasa untuk berdoa sebelum dan sesudah pembelajaran berlangsung. Kemudian, dengan menerapkan bagian Tri Hita Karana yang kedua yaitu Pawongan siswa akan terbiasa untuk berperilaku baik, memberikan salam, saling menghargai pendapat dan perbedaan dengan temannya, sehingga suasana kelas menjadi harmonis. Kemudian yang ketiga Palemahan, dengan penerapan bagian Tri Hita Karana yang terakhir ini siswa akan terbiasa untuk menjaga lingkungannya supaya tetap asri dan lestari".

Pengaruh Model Pembelajaran Kooperatif Tipe Tsts Terintegrasi Nilai Tri Hita Karana Terhadap Hasil Belajar IPS 

87-97.

\section{SIMPULAN}

Penelitian ini dilaksanakan pada semester II tahun pelajaran 2018/2019 di kelas IV SD di Gugus IV Kecamatan Sukasada. Jenis penelitian yang dilakukan adalah kuasi eksperimen atau eksperimen semu. Populasi dari penelitian ini adalah seluruh siswa kelas IV SD di Gugus IV Kecamatan Sukasada tahun pelajaran 2018/2019, yang berjumlah 165 siswa. Pemberian perlakuan pada kelas eksperimen dan kelas kontrol dilakukan masing-masing 8 kali dan di akhir perlakuan diberikan post-test pada kelas eksperimen dan kelas kontrol untuk memperoleh hasil belajar IPS siswa.

Berdasarkan hasil penelitian dan pembahasan dapat disimpulkan bahwa, terdapat perbedaan yang signifikan hasil belajar IPS tema cita-citaku antara siswa yang dibelajarkan dengan model pembelajaran kooperatif tipe Two Stay Two Stray terintegrasi Nilai Tri Hita Karana dan siswa yang tidak dibelajarkan dengan model pembelajaran kooperatif tipe Two Stay Two Stray terintegrasi Nilai Tri Hita Karana pada siswa kelas IV SD di Gugus IV Kecamatan Sukasada Tahun Pelajaran 2018/2019. Hal ini dapat dilihat dari hasil penghitungan menunjukkan bahwa rata-rata hasil belajar IPS siswa kelas eksperimen lebih rendah dari kelas kontrol $(24,44>16,2)$. Berdasarkan uji hipotesis yang telah dilakukan diperoleh $t_{\text {hitung }}=9,69$ dan $t_{\text {tabel }}$ dengan $\mathrm{dk}=25+23-2=46$, dan taraf signifikan $5 \%$ adalah 2,021. Dengan demikian $t_{\text {hitung }}(9,69)>t_{\text {tabel }}(2,021)$ maka $H 1$ diterima dan $\mathrm{HO}$ ditolak.

\section{DAFTAR PUSTAKA}

Dantes, Nyoman. 2012. Metode Penelitian. Yogyakarta: ANDI.

Huda, Miftahul. 2014. Model-model Pengajaran dan Pembelajaran. Yogyakarta: Pustaka Pelajar.

Koyan, I Wayan. 2012. Statistik Pendidikan Teknik Analisis Data Kuantitatif. Singaraja: Universitas Pendidikan Ganesha Press.

Murda, I Nyoman. dan Yudiana, I Kadek Edi. 2016. Bahan Ajar Konsep Dasar IPS. Singaraja: Universitas Pendidikan Ganesha.

Pebruanti, Lies. 2015. "Peningkatan Motivasi Dan Hasil Belajar Pada Mata Pelajaran Pemograman Dasar Menggunakan Modul Di SMKN 2 Sumbawa”. Jurnal Pendidikan Vokasi, Volume 5, Nomor 3 (hlm.368). Diakses pada tanggal 26 Januari 2019.

Peraturan Menteri Pendidikan Dan Kebudayaan Republik Indonesia Nomor 103 Tahun 2014 Tentang Pembelajaran Pada Pendidikan Dasar Dan Pendidikan Menengah. 2014. Jakarta: Kementerian Pendidikan dan Kebudayaan.

Prastowo, Andi. 2013. Pengembangan Bahan Ajar Tematik. Jogjakarta: DIVA Press.

Putra, I Wayan Weda Gustana. 2016. "Pengaruh Model Pembelajaran Savi Bermuatan Tri Hita Karana Terhadap Hasil Belajar Ipa Siswa Kelas IV". e-Journal PGSD Universitas Pendidikan Ganesha, Volume 4, Nomor 1 (hlm.8) Diakses pada tanggal 12 Juni 2019.

Ridwanthi, Kd Dian P. 2012. "Pengaruh Model Pembelajaran Kooperatif Tipe NHT Berbantuan Media Question Cards Terhadap Hasil Belajar Matematika Siswa Kelas IV SDN 6

Bondalem". e-Journal PGSD Universitas Pendidikan Ganesha, Volume 1, Nomor 1 (hlm.1). Diakses pada tanggal 25 Juni 2019.

Shoimin, Aris. 2014. 68 Model Pembelajaran Inovatif dalam Kurikulum 2013. Yogyakarta: ARRUZZ MEDIA. 
Ni Kadek Ratna, I Gusti Ngurah Japa, Ni Wayan Arini . (2019). Jurnal Pendidikan Multikultural Indonesia. Vol. 2 (2) pp. 87-97.

Susanto, Ahmad. 2013. Teori Belajar dan Pembelajaran di Sekolah Dasar. Jakarta: Prenadamedia Group.

Wardiana, Pt Arya., dkk. 2014. "Hubungan Antara Advesity Quotient (AQ) dan Minat Belajar dengan Prestasi Belajar Matematika pada Siswa kelas V SD Di Kelurahan. Journal Mimbar PGSD Universitas Pendidikan Ganesha. Volume 1, Nomor 1. Diakses pada tanggal 21 Juni 2019. 